\title{
Natural fluoride levels \\ from public water supplies in Piauí State, Brazil
}

\author{
Concentração de flúor in natura \\ em águas de abastecimento público no Piauí, Brasil
}

\author{
Josiene Saibrosa da Silva ${ }^{1}$ \\ Wallesk Gomes M oreno ${ }^{2}$ \\ Franklin Delano Soares Forte ${ }^{1}$ \\ Fábio Correia Sampaio ${ }^{1}$
}

\footnotetext{
${ }^{1}$ Programa de Pós Graduação em Odontologia M estrado em Odontologia Preventiva elnfantil, UFPB. CampusI Cidade Universitária 58051-900 J oão Pessoa PB. josiene@uol.com.br ${ }^{2}$ Secretaria de Saúde do Piauí.
}

Abstract The aim of this work was to determine the natural fluoride concentrations in public water supplies in Piauí State, Brazil, in order to identify cities in risk for high prevalence of dental fluorosis. For each city, two samples of drinking water were collected in the urban area: one from the main public water supply and another from a public or residential tap from the same source. Fluoride analyses were carried out in duplicate using a specific ion el ectrode and TISAB II. From a total of 222 cities in Piauí, 164 (73.8\%) samples were analyzed. Urban population in these towns corresponds to $92.5 \%$ of the whole state with an estimated population of 1,654,563 inhabitants from the total urban population $(1,788,590$ inhabitants). A total of 151 cities showed low fluoride levels ( $<0.30 \mathrm{mg} / \mathrm{L}$ ) and 13 were just below optimum fluoride concentration in the drinking water (0.31-0.59 mg/L). High natural fluoride concentration above $0.81 \mathrm{mg} / \mathrm{L}$ was not observed in any of the surveyed cities. As a conclusion, most of the cities in Piauí have low fluoride concentration in the drinking water. The risk for a high prevalence of dental fluorosis in these urban areas due to natural fluoride in the water supplies is very unlikely. Thus, surveys about the dental fluorosis prevalencein Piauí should be related with data about the consumption of fluoridated dentifrices and other fluoride sources.

Key words Dental caries, Fluoridation, Surveillance, Dental fluorosis
Resumo 0 objetivo destetrabalho foi realizar um levantamento dos teores residuais de flúor ( $F$ in natura) da água de abastecimento em municípios do Piauí para identificar localidades com risco de elevada prevalência defluorose dentária. Para cada município, foram coletadas duasamostras da água de abastecimento da zona urbana, uma amostra da principal fonte de abastecimento público do município e a outra de uma torneira pública ou residencial abastecida pela mesma fonte. Asanálises de flúor foram realizadas em duplicata, utilizando um el etrodo específico e TISAB II. Dos 222 municípiosdo Piauí, 164 (73,8\%) enviaram amostras para análise. A população urbana desses municípios correspondea 92,5\% (1.654.536 habitantes) da população urbana total do estado ( 1.788 .590 habitantes). O bservou-seque 151 municípiosapresentam baixos teores residuais de flúor ( $<0,30 \mathrm{mg} /$ L) e treze municípios apresentaram teores residuais abaixo do nível ideal (0,31 - 0,59 mg/L). Ne nhum município analisado apresentou teor residual de flúor acima do aceitável (>0,81 mg/L). Conclui-se quea maioria dos municípios do Piauí possui água deabastecimento com baixosteores de flúor residual. 0 risco de uma el evada prevalência defluorose dentária pelo flúor residual da água de abastecimento é pouco provável. Estudos sobre a prevalência de fluorose dentária no Piauí devem considerar outras fontes de flúor.

Palavras-chave Cárie dentária, Fluoração das águas, Vigilância sanitária, Fluorose dentária 


\section{Introduction}

In the Northeastern region of Brazil some inland cities from Paraíba and Ceará have moderate to high natural fluoridelevels $(>1.0 \mathrm{mg} / \mathrm{L}$ ) in thedrinking water resulting in high prevalence of dental fluorosis and some severe cases $^{1-3}$. In Rio Grande do Norte, Paz et al. ${ }^{4}$ observed natural fluoride concentrations up to $1.1 \mathrm{ppm}(\mathrm{mg} / \mathrm{L})$, and in such areasseverecases of dental fluorosisislikely to occur due to high local temperatures and a high consumption of rich fluoridedrinking water.

It is estimated that in the Northeastern region of Brazil only $16.5 \%$ of the cities have water fluoridation systems ${ }^{5}$. Therefore, the recent federal program named "Brasil Sorridente" has given theopportunity to implement water fluoridation systems in many cities of the Northeastern region where technical requirements for potable water are accomplished ${ }^{6,7}$. Evaluation of the natural fluorideconcentration in the drinking water is important since this information is relevant to establish the ideal concentration of fluoride in the drinking water in accordance to the mean annual temperature $\mathrm{e}^{8,9}$.

The mean annual temperature in Piauí is around $28^{\circ} \mathrm{C}^{10}$. Therefore, the optimal fluoride concentration in the drinking water is around 0.7 $\mathrm{mg} / \mathrm{L}$ with accepted values between 0.6 and 0.8 $\mathrm{mg} / \mathrm{L}^{11}$. In Piauí, three cities have artificial water fluoridation systems: Parnaíba, Floriano and Teresina $^{12,13}$. The Parnaíba River is the only source of water for thesecities and the residual fluorideconcentration is low ${ }^{14}$. However, the state of Piauí has a great deal of its territory placed in the semi-arid region where wells are the only source of drinking water available $\mathrm{e}^{10}$. The probability of having higher fluoride concentrations in underground waters than in surface waters has al ready been observed in many parts of the world including in the Northeast region of Brazil ${ }^{3,15}$. Thus, the aim of this study was to determine the natural fluoride concentration in public water supplies in Piauí State, Brazil, in order to identify cities at risk for high prevalence of dental fluorosis.

\section{Methods}

\section{Areas under study}

The state of Piauí has 222 cities and an estimated population of $2,843,278$ inhabitants ${ }^{16}$. It is also estimated that $63 \%$ lives in urban areas (1,788,590 inhabitants). The annual averagetemperature in Piauí ishigh and around $28^{\circ} \mathrm{C}$ in most part of its territory ${ }^{10}$.

\section{Water samples collection and analysis}

In each city at least two samples of the drinking water were collected. One sample was from the main public water supply and another from a public or residential tap from the same source. TheH ealth Secretariat of the State of Piauí (SESA$\mathrm{PI}$ ) informed to all local authorities about the methodology of water samples collection. The samples were collected by local sanitary vigilance workers. Plastic recipients of $500 \mathrm{~mL}$ were distributed and they were requested to identify the samples (city, address, date of collection and water source) in accordance to methods reported by Funasa, $2004^{17}$. J ust after collection, thesamples were transported by fast mail to the Laboratory of Oral Biology at Federal University of Paraíba where the analyses were carried out.

All the samples were analyzed within 30 days after collection. The procedures were in duplicate using a fluoride specific electrode (Orion model 9609 , Orion Research Inc., USA) coupled to an ion analyzer meter (Orion model 710-A, Orion $\mathrm{Re}$ search Inc., USA). The samples were analyzed in 1:1 with TISAB II. Calibration was frequently carried out with fresh fluoride standards of $1 \mathrm{~mL}$ of 0.2 up to $1.6 \mathrm{mg} / \mathrm{L}$. The data in $\mathrm{mV}$ were transformed in $\mu \mathrm{g}$ of fluoride and in fluoride concentration (mg/L) using a Windows-Excel file. Only calibration curves with variation in percentageuntil $5 \%$ for all standards and $r^{3} 0.99$ were accepted.

The mean SD of the residual fluoride concentrations of each city was calculated from the two samples obtained. The mean SD of few cities was calculated from three or four original samples due to different water sources in the same urban area. The data were classified according to the fluoride concentration in $\mathrm{mg} / \mathrm{L}$ in four groups: 1) from 0.01 to $0.30 \mathrm{mg} / \mathrm{L}$ (very low $\mathrm{F}$ concentration); 2) from 0.31 to $0.59 \mathrm{mg} / \mathrm{L}$ (low $F$ concentration); 3) from 0.60 to $0.80 \mathrm{mg} / \mathrm{L}$ (optimum $\mathrm{F}$ concentration) and 4) above $0.81 \mathrm{mg} / \mathrm{L}$ (high F concentration).

\section{Results}

From 222 towns in Piauí, 164 (73.8\%) samples were sent for fluoride analyses. Based on the estimates of IBGE, $2000^{16}$, the urban population of all these cities corresponds to $92.5 \%(1,654,536$ inhabitants) from the total urban population in Piauí (1,788,590 inhabitants).

In Table 1, it is observed that 151 cities presented very low natural $F$ concentration, whereas 13 showed low natural $F$ concentration. 
Table 2 shows that the 13 cities with low natural $\mathrm{F}$ concentrations in the drinking water are in small cities covering approximately 80,000 inhabitants.

Table 3 lists all cities according to their distribution in the regional health offices and natural $F$ concentration in the water.

Table 4 relates the official data of caries as DM FT recorded by SB Brasil (2003) in the same cities where water samples could be analyzed. Note that for Teresina artificial water fluoridation is available.

\section{Discussion}

This work applied standard methodologies to collect and determine water fluoride concentra- tions, 17. The set up of two samples of the main water source from urban areas was established due to fact that in few cities of Piauí a record of more than one source of water could take place particular during drought periods ${ }^{19}$. However, there are few publications about water quality and supplies in Piauí. Water quality vigilance is implemented in 171 cities and so far there is no data about natural fluoride concentrations in thesecities ${ }^{18}$.

From the 222 cities contacted $74 \%$ responded and sent water samples for analysis (Table 1). It can be estimated that this work covers drinking water sources of almost all inhabitants of the urban areas in Piauí ${ }^{16}$. The 58 cities that are not covered in this research would give water samples of small cities that represent only $7.5 \%$ of the total urban population in the state.

Table 1. Number of cities according to the natural fluoride levels in the drinking water and estimated population exposed.

\begin{tabular}{|c|c|c|c|c|}
\hline \multirow{2}{*}{ Fluoride levels (mg/L) } & \multicolumn{2}{|c|}{ Cities } & \multicolumn{2}{|c|}{ Urban population* } \\
\hline & $\mathrm{N}$ & $\%$ & $n$ & $\%$ \\
\hline 0.01 a 0.30 & 151 & 92.0 & $1,594,269$ & 96.3 \\
\hline 0.31 a 0.59 & 13 & 8.0 & 60,267 & 3.7 \\
\hline Above 0.60 & - & - & - & - \\
\hline Total & 164 & 100.0 & $1,654,536$ & 100.0 \\
\hline
\end{tabular}

* Source: IBGE, $2000^{16}$.

Table 2. List of cities and estimated population exposed to natural fluoride concentration in the drinking water above $0.30 \mathrm{mg} / \mathrm{L}$.

\begin{tabular}{lcccc}
\hline \multicolumn{1}{c}{ City } & Samples (n) & Mean (SD) Fluoride $(\mathrm{mg} / \mathrm{L})$ & Source* & Estimated population ** \\
\hline Angical do Piauí & 2 & $0.47(0.14)$ & $\mathrm{N} \mathrm{A}$ & 5,065 \\
Curral N ovo do Piauí & 2 & $0.46(0.00)$ & $\mathrm{W}$ & 1,050 \\
Dom Inocêncio & 2 & $0.42(0.02)$ & $\mathrm{W}$ & 856 \\
Francisco M acedo & 2 & $0.50(0.08)$ & $\mathrm{N} \mathrm{A}$ & 639 \\
Ipiranga do Piauí & 2 & $0.39(0.04)$ & $\mathrm{N} \mathrm{A}$ & 4,923 \\
Jacobina do Piauí & 2 & $0.56(0.00)$ & $\mathrm{N} \mathrm{A}$ & 851 \\
Jatobá do Piauí & 2 & $0.36(0.11)$ & $\mathrm{N} \mathrm{A}$ & 657 \\
Luzilândia & 2 & $0.42(0.00)$ & $\mathrm{N} \mathrm{A}$ & 13,453 \\
M iguel Alves & 2 & $0.46(0.00)$ & $\mathrm{W}$ & 9,609 \\
M iguel Leão & 2 & $0.36(0.05)$ & $\mathrm{N} \mathrm{A}$ & 749 \\
Pio IX & 2 & $0.49(0.12)$ & $\mathrm{N} \mathrm{A}$ & 4,278 \\
São Braz do PI & 2 & $0.37(0.04)$ & $\mathrm{L}$ & 935 \\
São Raimundo Nonato & 2 & $0.43(0.08)$ & $\mathrm{N} \mathrm{A}$ & 17,202 \\
Total & & - & - & 80,438 \\
\hline
\end{tabular}

* $W=$ well, $L=$ lake; $N A=$ not available

** Estimated population based on IBGE records for the year $2000^{16}$. 
Table 3. List of cities in Piauí according to the natural $\mathrm{F}$ levels in the drinking water and regional health offices.

\begin{tabular}{|c|c|c|}
\hline N* & Cities according to fluoride levels (mg/L) & \\
\hline & 0.01 a 0.30 & 0.31 а 0.59 \\
\hline I & $\begin{array}{l}\text { Buriti dos Lopes, Caraúbas, Caxingó, Cocal, Cocal dos Alves, Ilha } \\
\text { Grande, Luis Correia, Murici dos Portelas, Parnaíba. }\end{array}$ & - \\
\hline II & $\begin{array}{l}\text { Barras, Batalha, Cabeceiras do Piauí, Campo Largo, Esperantina, } \\
\text { J. Pires, J. M arques, M adeiro, M atias Olímpio, Morro do Chapéu } \\
\text { do Piauí, N. Senhora dos Remédios, Porto, S. João do Arraial. }\end{array}$ & Luzilândia. \\
\hline III & $\begin{array}{l}\text { Brasileira, Capitão de Campos, Domingos M ourão, Lagoa de S. } \\
\text { Francisco, Milton Brandão, Pedro II, Piracuruca, Piripiri, S. José } \\
\text { do Divino. }\end{array}$ & - \\
\hline IV & $\begin{array}{l}\text { Altos, Curralinhos, Demerval Lobão, José de Freitas, Lagoa do } \\
\text { Piauí, M onsenhor Gil, Palmeirais, Teresina, União. }\end{array}$ & Miguel Alves. \\
\hline $\mathrm{V}$ & $\begin{array}{l}\text { Alto Longa, Assunção do Piauí, Boqueirão do Piauí, Campo } \\
\text { Maior,Castelo do Piauí, Cocal de Telha, Coivaras, Juazeiro do } \\
\text { Piauí, Nossa Senhora de Nazaré,N ovo Santo Antônio. }\end{array}$ & Jatobá do Piauí. \\
\hline VI & $\begin{array}{l}\text { Agricolândia, Água Branca, Amarante, Arraial, Barro Duro, } \\
\text { Hugo N apoleão, Lagoinha do Piauí, Passagem, Franca do Piauí, } \\
\text { Regeneração, S. Gonçalo do Piauí, S. Pedro do Piauí. }\end{array}$ & $\begin{array}{l}\text { Angical do Piauí, Miguel } \\
\text { Leão. }\end{array}$ \\
\hline VII & $\begin{array}{l}\text { Aroazes, B. d’Álcântara, Elesbão Veloso, Francinópolis, Inhuma, } \\
\text { N. Oriente do Piauí, Pimenteiras, Prata, S. C. dos M ilagres,S. } \\
\text { Felix do Piauí,Valença do Piauí, Várzea Grande. }\end{array}$ & - \\
\hline VIII & $\begin{array}{l}\text { Cajazeiras do PI, Campinas do PI, Colônia do PI, Floresta do } \\
\text { Piauí, I saías Coelho, Oeiras, Santa Rosa do PI, S. Francisco do } \\
\text { Piauí,S. José do Peixe, S. M iguel do Fidalgo,Tanque do PI. }\end{array}$ & 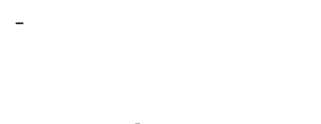 \\
\hline $\mathrm{IX}$ & $\begin{array}{l}\text { D. Expedito Lopes, Itainópolis, Jaicós, M assapê do PI, Picos, S. } \\
\text { Cruz do PI, Santana do PI, S. João da Canabrava, Sussuapara. }\end{array}$ & Ipiranga do Piauí, \\
\hline$X$ & $\begin{array}{l}\text { Canavieira, Colônia do Gurguéia, Eliseu Martins, Flores do Piauí, } \\
\text { Floriano,Guadalupe, Landri Sales, M anoel Emídio, Marcos } \\
\text { Parente, Nazaré do Piauí, Pavussu. }\end{array}$ & - \\
\hline $\mathrm{XI}$ & $\begin{array}{l}\text { Bela Vista do PI, Brejo do PI, Capitão G. Oliveira, J. Costa, } \\
\text { Lagoa do Barro do PI,Pedro Laurentino, Ribeira do PI, São João } \\
\text { do PI, Simplício M endes, Tamboril do PI. }\end{array}$ & 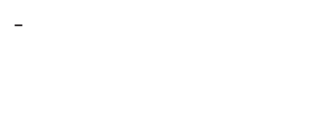 \\
\hline $\mathrm{XII}$ & $\begin{array}{l}\text { Anísio de Abreu, Caracol, Coronel José Dias, D. Arcoverde, } \\
\text { Fartura do Piauí, Guaribas, Jurema, Nova Santa Rita, Rio Grande } \\
\text { do PI, S. Lourenço do PI,Várzea Branca. }\end{array}$ & $\begin{array}{l}\text { D. Inocêncio, S. } \\
\text { Raimundo Nonato, S. } \\
\text { Braz do PI. }\end{array}$ \\
\hline $\mathrm{XIII}$ & $\begin{array}{l}\text { Alvorada do Gurguéia, Bom Jesus, Cristino Castro, Currais, } \\
\text { Redenção do Gurguéia, ,Santa Luz }\end{array}$ & - \\
\hline XIV & $\begin{array}{l}\text { Barreiras do PI, Corrente, Curimatá, Júlio Borges, M onte Alegre } \\
\text { do Piauí, M orro Cabeça no Tempo, Riacho Frio, Sebastião } \\
\text { Barros. }\end{array}$ & - \\
\hline$X V$ & $\begin{array}{l}\text { Antônio Almeida, Baixa Grande do Ribeiro, Porto Alegre do } \\
\text { Piauí, Uruçuí }\end{array}$ & - \\
\hline $\mathrm{XVI}$ & Caridade do Piauí, Fronteiras, Padre M arcos, São Julião. & $\begin{array}{l}\text { C. Novo do Piauí, F. } \\
\text { Macedo, Pio IX. }\end{array}$ \\
\hline XVI & $\begin{array}{l}\text { Patos do Piauí, Paulistana, Queimada Nova, S. Francisco de } \\
\text { Assis do Piauí. }\end{array}$ & Jacobina do Piauí. \\
\hline
\end{tabular}

$* \mathrm{~N}=$ Regional Health Office number.

Thirteen cities in Piauí showed residual fluorideconcentrations above $0.31 \mathrm{mg} / \mathrm{L}$. Thehighest concentration of natural fluoridein the water was found in Jacobina do Piauí with $0.56 \mathrm{mg} / \mathrm{L}$ (Table 2 and 3). This level of fluorideisclose to "optimal" fluoride concentration in the water according to 
Table 4. Natural fluoride concentration in the drinking water and DM FT index*.

\begin{tabular}{llcrcc}
\hline \multicolumn{1}{c}{ City } & \multicolumn{2}{c}{ DMFT (SD)* } & M ean (SD) natural F in $\mathrm{mg} / \mathrm{L}$ & Artificial fluoridation \\
\hline Tamboril do PI & 5.49 & $(4.05)$ & 0.04 & $(0.00)$ & no \\
Marcos Parente & 5.25 & $(3.75)$ & 0.04 & $(0.00)$ & no \\
Coronel José Dias & 5.04 & $(3.41)$ & 0.08 & $(0.05)$ & no \\
Júlio Borges & 3.63 & $(3.01)$ & 0.30 & $(0.14)$ & no \\
Teresina & 2.52 & $(2.48)$ & 0.08 & $(0.00)$ & yes \\
\hline
\end{tabular}

* DM FT data from SB-Brasil ${ }^{18}$.

the local mean annual temperature. Two other cities were also close to these values. However, most of them have few inhabitants. The most populated city with natural fluoride in the water was São Raimundo Nonato with an estimated population of almost 20 thousand inhabitants. Seven cities with natural fluoride levels above 0.3 $\mathrm{mg} / \mathrm{L}$ are located in the Central and Southeast part of the state in four Health Regional Offices numbers: IX, XI, XVI and XVII. This was expected since in the N ortheast region the presence of natural fluoride is higher in wells located in crystalline soils in the semi-arid zone ${ }^{3}$. Therefore, it can be expected that most of the cities with natural $\mathrm{F}$ concentrations close to $0.5 \mathrm{mg} / \mathrm{L}$ would be closer to Ceará border where a similar situation can be observed ${ }^{1}$. This is probably the region in Piauí where rural communities might have elevated fluoride levels in the drinking water due to its geological pattern of crystalline soils ${ }^{3}$.

The $\mathrm{F}$ concentrations data obtained in this study represent a punctual value of fluoride for each city and do not reflect possiblefluoridefluctuations. However, one cannot disregard the fact that the data can provide an estimate of fluoride exposureamong the permanent residents of those cities. For those cities with $\mathrm{F}$ concentrations above $0.5 \mathrm{mg} / \mathrm{mL}$, the data are relevant because it can indicate a moderate or a high fluoride intake among children and consequently a potential risk for dental fluorosis. M ost cities in Piauí showed low natural $\mathrm{F}$ concentrations in the drinking water, but these data of low $F$ exposure from the water are important because they are the basic technical information for implementing water fluoridation programs in the near future 5 .

Although few cities had been investigated for dental caries in Piauí, Table 4 gives a rough picturethat fluoridein the drinking water can play a role for controlling caries prevalence. Recently, Ramirez et al. ${ }^{20}$ pointed out several positivearguments for implementing water fluoridation in areas where caries is a prevalent condition. The fact that water fluoridation does not have a selective risk approach for controlling caries is not a strong argument to avoid its implementation. In Piauí, as well as in many states in the N ortheastern region, water fluoridation might bequestioned more due to economical, political and philosophical reasons rather than scientific ones.

Certainly the use of fluoridated dental products and other related variables for caries control cannot be disregarded for a complete evaluation about fluoride exposures ${ }^{21,22}$. Regarding dental fluorosis, it is very unlikely that the severe cases of dental fluorosis, if there is any, can be attributed solely to the natural $F$ in thedrinking water. Cities in the N ortheastern region with $0.4 \mathrm{mg} / \mathrm{L}$ of fluoride show in general $20 \%$ of children with dental fluorosis and most of them without aesthetic concern ${ }^{23}$. H owever, fluoride intake among children in living in the Northeastern regions suggests that theF-intakeis 2 fold higher than in children from the Southeastern region of the country ${ }^{24}$. This is mainly due to the use of $1,500 \mathrm{ppm}$ fluoridated toothpaste for children. How far this is also a trend in Piauí, this is a matter of investigation. A survey about theconsumption of fluoridated dentifrice by children in Piauí and its contribution for dental fluorosis is warranted since contribution of water $\mathrm{F}$ in many cities can beal ready estimated.

\section{Conclusion}

It can be concluded that most of the cities in Piaui have low fluoride concentration in the drinking water. The risk for a high prevalence of dental fluorosis in these urban areas due to the natural fluoride content in the water supplies is very unlikely. Thus, for themajority of the cities of Piauí, surveys about the dental fluorosis prevalence should be related with data about the consumption of fluoridated dentifrices and other fluoride sources. 


\section{Collaborators}

JS Silva conceived and worked out the methodology, and wrote down this paper. VW Moreno worked out the methodology. FDS Forte worked out themethodology. FC Sampaio conceived and revised this paper.

\section{Acknowledgements}

This study was supported by CAPES and CN Pq 403241/2004-9.

\section{References}

1. Bleicher L, Frota FHS. Panorama da fluoretação da água de abastecimento em municípios cearenses. Rev da Aboprev 2003; 5(1):13-21.

2. Cortes DF, Ellwood RP, Mullane DM O, Bastos JRM Drinking water fluoride levels, dental fluorosis and caries experience in Brazil. J Public Health Dent 1996; 56(4):226-228.

3. Sampaio FC, Ramm von der Fehr F, Arneberg $P$, Petrucci Gigante D, Hatløy A. Dental fluorosis and nutritional status of 6 - to 11 -year-old children living in rural areas of Paraíba, Brazil. Caries Res. 1999; 33(1):66-73.

4. Paz RS, Lima KC, Sampaio FC, Leite MJF. Relação entre as características geomorfológicas e teor de flúor natural nas águas de abastecimento no Rio Grande do Norte. Braz. oral res 2004; 18(Supl.):31.

5. Brasil. Ministério da Saúde. Fundação Nacional de Saúde. Programa Brasil Sorridente - sub-componente fluoretação da água (versão preliminar II 23/05/ 05), 2005. [Dados não publicados]

6. Brasil. M inistério da Saúde. Secretaria de atenção à saúde. Departamento de atenção básica. Coordenação nacional de Saúde Bucal. Projeto SB Brasil 2003: condições de saúde bucal da população brasileira no ano 2002-2003. Resultados Principais. Brasília: Ministério da Saúde; 2004.

7. Funasa. Ministério da Saúde. Programa Brasil Sorridente, a saúde bucal levada a sério - sub-componente fluoretação da água. M anual de Orientações Técnicas. Brasília: Ministério da Saúde; 2006.

8. Buzalaf MAR, Granjeiro JM, Damante CA, Ornelas F. Fluctuations in public water fluoride levels in Bauru, Brazil. J Public Health Dent 2002; 62(3):173-176.

9. Schneider Filho DA, Prado IT, Narvai PC, Barbosa SE. Fluoretação da água. Como fazer a vigilância sanitária? Rio de Janeiro: Rede CEDROS; 1992.

10. Silva N eto FS, Santos VS. H istória e Geografia do Piauí. 2ª ed. Teresina: Freire \& Comp. Ltda; 1994.

11. Galagan DJ, Vermillion JR. Determining optimum fluoride concentrations. Public Health Rep 1957; 72(6):491-493.

12. Empresa de Tratamento de Águas de Esgotos do Piauí (Agespisa). Declaração 24 Out. 2005. Teresina: Agespisa; 2005.
13. Silva JS, Val CM, Costa JN, Moura MS, Silva TA, Sampaio FC. M onitoring water fluoridation in three cities in Piauí State, Brazil. Cad Saude Publica 2007; 23(5):1083-1088.

14. Moura MS, Silva JS, Simplício AHM, Cury JA. Avaliação longitudinal da fluoretação da água de abastecimento público de Teresina-Piauí. Rev Odonto Ciência 2005; 20(48):132-136.

15. Whitford GM. The metabolism and toxicity of fluoride. M onographs in oral science. Basel: Karger; 1996.

16. Instituto Brasileiro de Geografia e Estatística. População e Domicílios - Censo 2000. [acessado 2004 ago 18]. Disponível em: http: //www.ibge.gov.br/cidadesat/default.php

17. Funasa. Fundação Nacional de Saúde. Manual de Saneamento. 3a ed. Brasília: Funasa; 2004.

18. Brasil. M inistério da Saúde. Projeto SB Brasil, 2003. Banco de dados originais. [Dados não publicados]. Atlas do Abastecimento da Água do Piauí. Abastecimento de sedes municipais com menos de 5000 habitantes - Resumo Executivo. 2005 [acessado 2005 jul 26]. Disponível em: http://www.pi.gov.br/banco dados.php

19. Ramires I, Buzalaf MAR. A fluoretação da água de abastecimento público e seus benefícios no controle da cárie dentária - cinqüenta anos no Brasil. Cien Saude Colet 2007; 12(4):1057-1065.

20. Brunelle JA, Carlos JP. Recent trends in dental caries in U.S. children and the effect of water fluoridation. J Dental Res 1990; 69(Special Issue):723-727.

21. Ripa LW. A half-century of community water fluoridation in the United States: review and commentary. J Public Health Dent 1993; 53(1):17-44.

22. Forte FD, Freitas CH, Sampaio FC, Jardim MC. Fluorose dentária em crianças de Princesa Isabel, Paraíba. Pesqui Odontol Bras 2001;15(2):87-90.

23. Omena LM F, Silva M FA, Pinheiro CC, Cavalcante JC, Sampaio FC. Fluoride intake from drinking water and dentrifice by children living in a tropical área of Brazil. J Appl Oral Sci 2006; 14(5):382-387.

Artigo apresentado em 20/11/07

Aprovado em 15/02/2007

Versão final apresentada em 31/03/2008 